\title{
PERBANDINGAN KEPEMIMPINAN KLINIS PERAWAT BERDASARKAN PENDEKATAN CLINICAL LEADERSHIP COMPETENCY FRAMEWORK DI RUMAH SAKIT PEMERINTAH DENGAN RUMAH SAKIT SWASTA DI KUTACANE TAHUN 2019
}

\author{
Yusnaini $^{1}$, Lisnawati Lubis ${ }^{2}$ \\ 1,2 Program Studi Ners STIKes Nurul Hasanah Kutacane \\ Email: yusnaini84@gmail.com.
}

\begin{abstract}
Abstrak
Perawat memiliki peran penting dalam pemberian pelayanan kesehatan di rumah sakit. Kepemimpinan klinis merupakan suatu kemampuan yang mendukung peran perawat pada semua level manajerial. Simon (2014) dan Ferguson, et all. (2007), mendefinisikan kepemimpinan klinis merupakan kompetensi yang mendukung peningkatan kualitas dan keselamatan pasien secara inovasi dan kreativitas dalam praktek keperawatan. Penelitian Ruedy, J. dan Ogilvie, R. (2004), menyebutkan Kejadian Tidak Diharapkan (KTD) di rumah sakit pendidikan Kanada diperkirakan 24\% dan 62\% disebabkan efek samping dari pemberian obat, 9\% infeksi nasokomial. KTD tersebut berkaitan dengan kurangnya kemimpinan klinis perawat dalam menjamin keselamatan pasien selama perawatan. Penelitian ini bertujuan untuk mengetahui perbandingan kepemimpinan klinis perawat berdasarkan pendekatan clinical leadership competence framework di rumah sakit pemerintah dengan rumah sakit swasta di Kutacane. Metode penelitian bersifat kuantitatif dengan pendekatan cross sectional. Hasil penelitian didapatkan bahwa tidak ada perbedaan antara kepemimpinan klinis perawat berdasarkan pendekatan clinical leadership competence framework pada rumah sakit pemerintah dan rumah sakit swasta di Kutacane. Kepemimpinan klinis sangat penting bagi perawat, diharapkan pihak manajerial rumah sakit memberikan dukungan bagi perawat melalui pendidikan, pelatihan dan mengevaluasi efektifitas kepemimpinan klinis berdasarkan clinical leadership competence framework.
\end{abstract}

Kata kunci: Kepemimpinan, Klinis, Perawat, Competency

\begin{abstract}
Nurses have an important role in providing health services in hospitals. Clinical leadership is an ability that supports the role of nurses at all managerial levels. Simon (2014) and Ferguson, et all. (2007), defining clinical leadership is a competency that supports the improvement of patient quality and safety through innovation and creativity in nursing practice. Ruedy, J. and Ogilvie, R. (2004), states that the adverse events in Canadian teaching hospitals are estimated to be $24 \%$ and $62 \%$ due to side effects of drug administration, 9\% of nosocomial infections. The adverse events is related to the lack of clinical leadership of nurses in ensuring patient safety during treatment. This study aims to compare the nurse's clinical leadership based on the approach of the clinical leadership competency framework at a government hospital with a private hospital in Kutacane. The research method is quantitative with a cross-sectional approach. The results showed that there was no difference between nurse clinical leadership based on the clinical leadership competency framework approach at government hospitals and private hospitals in Kutacane. Clinical leadership is very important for nurses, it is expected that managerial hospitals provide support for nurses through education, training and evaluating clinical leadership effectiveness based on the clinical leadership competency framework.
\end{abstract}

Keywords: Leadership, Clinical, Nursing, Competency

\section{PENDAHULUAN}

Perawat merupakan tenaga kesehatan profesional yang berperan dalam pelayanan kesehatan. Kepemimpinan klinis merupakan bagian penting dari peran perawat, terlepas dari posisinya dalam institusi rumah sakit 
Yusnaini', Lisnawati Lubis ${ }^{2}$, Perbandingan Kepemimpinan Klinis Perawat berdasarkan Pendekatan Clinical Leadership Competency Framework di Rumah Sakit Pemerintah dengan Rumah Sakit Swasta di Kutacane Tahun 2019

(Willcocks, 2012). Kepemimpinan klinis adalah kompetensi yang tepat bagi perawat meningkatkan kualitas dan keselamatan pasien melalui inovasi dan kreativitas dalam praktek keperawatan (Simon, 2014; Ferguson, et all (2007). Kepemimpinan klinis membantu perawat memberikan asuhan keperawatan bagi pasien.

Perawat dengan kepemimpinan klinis yang kurang baik menjadi masalah sistem pelayanan kesehatan. Menurut Doherty, J. (2014), kepemimpinan klinis yang belum optimal menjadi masalah manajemen rumah sakit dan berpengaruh terhadap rendahnya kualitas pelayanan. Keadaan ini dikarenakan, sebagian besar keputusan mempengaruhi perawatan klinis. Kejadian Tidak Diharapkan (KTD) dirumah sakit pendidikan Kanada diperkirakan 24\% dari 731 pasien dan 62\% dari 502 pasien disebabkan efek samping dari pemberian obat, $9 \%$ infeksi nasokomial (Ruedy, J. \& Ogilvie, R., 2004). Hal ini berkaitan dengan kurangnya kemimpinan klinis perawat menjamin keselamatan pasien selama perawatan. Jadi kepemimpinan klinis perawat yang rendah berdampak terhadap pelayanan dan masalah manajemen.

Kepemimpinan klinis perawat harus dikembangkan melalui model yang sesuai bagi perawat. National Health Service (NHS) (2012), mengembangkan 1 (satu) model kepemimpinan klinis yaitu Clinical Leadership Competency Framework (CLCF). Menurut
Mortlock, Sue menyatakan kerangka kepemimpinan CLCF diakui sebagai model kepemimpinan klinis keperawatan (NHS, 2011). CLCF menjadi standar perilaku kepemimpinan perawat dalam pengembangan kepemimpinan klinis dan memberikan dukungan pengambilan keputusan klinis selama perawatan pasien (Blaber \& Harris, 2014). Hal ini menunjukkan bahwa CLCF menjadi standar perilaku kepemimpinan klinis bagi perawat dalam pengelolaan layanan keperawatan yang aman dan efisien.

Perawat dapat mengaplikasikan CLCF dalam pemberian asuhan keperawatan baik di rumah sakit pemerintah maupun rumah sakit swasta. Peneliti melakukan studi pendahuluan di RSUD H. Sahudin Kutacane dan RS Nurul Hasanah tentang kepemimpinan klinis perawat melalui wawancara. Kabid. Keperawatan RSUD H. Sahudin Kutacane mengatakan belum ada studi khusus yang dilakukan tentang kepemimpinan klinis perawat, ketersediaan sumber daya perawat sebagian besar merupakan tenaga honorer dan setiap ruang rawat inap hanya memiliki 3 perawat berstatus PNS. Keadaan ini mempengaruhi kemampuan perawat dalam pengembangan layanan keperawatan dan kemandirian perawat dalam pengambilan keputusan tentang perawatan pasien. Sedangkan Ka.Subid Keperawatan RS Nurul Hasanah mengatakan bahwa perawat belum maksimal melakukan intervensi keperawatan secara mandiri dan 
mengaplikasikan hasil penelitian dalam pemberian asuhan keperawatan. Hal ini menunjukkan bahwa perawat RSUD $H$. Sahudin Kutacane dan RS Nurul Hasanah belum optimal mengaplikasikasikan kepemimpinan klinis dalam pelayanan keperawatan

Penelitian studi perbandingan ini akan dilakukan di rumah sakit pemerintah dan rumah sakit swasta yang memiliki kebijakan, sarana dan prasarana yang berbeda. Perbedaan ini akan mempengaruhi perawat dalam pengambilan keputusan selama perawatan pasien di rumah sakit, sehingga rumah sakit penting untuk memperhatikan kepemimpinan klinis yang dimiliki oleh perawat

Berdasarkan latar belakang di atas, peneliti melakukan penelitian mengenai "Perbandingan Kepemimpinan Klinis Perawat Berdasarkan Pendekatan Clinical Leadership Competence Framework di Rumah Sakit Pemerintah dan Rumah Sakit Swasta”.

\section{METODE PENELITIAN}

Jenis penelitian yang digunakan dalam penelitian ini adalah jenis penelitian kuantitatif dengan desain Cross Sectional Study. Kemudian dilakukan uji beda independent sample t-test untuk mengetahui perbedaan kepemimpinan klinis perawat di Rumah Sakit Pemerintah dan Rumah Sakit swasta.

Penelitian ini dilaksanakan pada tanggal 27 Februari sampai 08 April 2019 di Rumah
Sakit Umum Daerah H. Sahudin Kutacane sebagai rumah sakit pemerintah dan Rumah Sakit Nurul Hasanah sebagai rumah sakit swasta

Populasi dalam penelitian ini adalah 105 perawat yang terdiri dari 43 perawat berstatus PNS yang bertugas di RSUD H. Sahudin dan 62 perawat berstatus pegawai tetap bertugas di RS Nurul Hasanah.

Analisis data yang digunakan pada penelitian ini adalah analisis univariat dengan menampilkan distribusi frekuensi untuk melihat variasi dari setiap variabel dan analisis bivariat untuk melihat perbandingan kepemimpinan klinis perawat berdasarkan pendekatan clinical leadership competence framework di rumah sakit pemerintah dan rumah sakit swasta.

\section{HASIL PENELITIAN}

Berdasarkan penelitian yang dilakukan di Rumah Sakit Pemerintah dan Rumah Sakit Swasta di Kutacane terhadap 105 perawat, didapatkan hasil penelitian sebagai berikut:

\section{Analisis Univariat}

Tabel 1

Distribusi Frekuensi Kepemimpinan Klinis Perawat di Rumah Sakit Pemerintah dan Rumah Sakit Swasta di Kutacane Tahun 2019

\begin{tabular}{clcccc}
\hline No & \multicolumn{1}{c}{ Variabel } & \multicolumn{2}{c}{ Pemerintah } & \multicolumn{2}{c}{ Swasta } \\
\cline { 3 - 6 } & & $\mathrm{f}$ & $\%$ & $\mathrm{f}$ & $\%$ \\
\hline 1. & Kepemimpinan & & & & \\
& Klinis & & & & \\
& $\bullet \quad$ Baik & 22 & 51,2 & 33 & 53,2 \\
& $\bullet \quad$ Kurang & 21 & 48,8 & 29 & 46,8 \\
& Sub Variabel & & & & \\
2. & Kualitas Diri & & & & \\
& $\bullet \quad$ Baik & 26 & 60,5 & 40 & 64,5 \\
& $\bullet \quad$ Kurang & 17 & 39,5 & 22 & 35,5 \\
\hline
\end{tabular}


Yusnaini' ${ }^{1}$, Lisnawati Lubis ${ }^{2}$, Perbandingan Kepemimpinan Klinis Perawat berdasarkan Pendekatan Clinical Leadership Competency Framework di Rumah Sakit Pemerintah dengan Rumah Sakit Swasta di Kutacane Tahun 2019

\begin{tabular}{|c|c|c|c|c|c|}
\hline \multirow[t]{2}{*}{ No } & \multirow[t]{2}{*}{ Variabel } & \multicolumn{2}{|c|}{ Pemerintah } & \multicolumn{2}{|c|}{ Swasta } \\
\hline & & $\mathrm{f}$ & $\%$ & $\mathrm{f}$ & $\%$ \\
\hline \multirow[t]{3}{*}{3.} & Kerjasama & & & & \\
\hline & - Baik & 25 & 58,1 & 34 & 54,8 \\
\hline & - Kurang & 18 & 41,9 & 28 & 45,2 \\
\hline \multirow[t]{3}{*}{4.} & $\begin{array}{l}\text { Manajemen asuhan } \\
\text { keperawatan }\end{array}$ & & & & \\
\hline & - Baik & 24 & 55,8 & 41 & 66,1 \\
\hline & - Kurang & 19 & 44,2 & 21 & 33,9 \\
\hline \multirow[t]{3}{*}{5.} & $\begin{array}{l}\text { Pengembangan } \\
\text { layanan } \\
\text { keperawatan }\end{array}$ & & & & \\
\hline & - Baik & 24 & 55,8 & 32 & 51,6 \\
\hline & - Kurang & 19 & 44,2 & 30 & 48,4 \\
\hline \multirow[t]{4}{*}{6.} & $\begin{array}{l}\text { Kemampuan } \\
\text { change agent }\end{array}$ & & & & \\
\hline & - Baik & 22 & 51,2 & 34 & 54,8 \\
\hline & - Kurang & 21 & 48,8 & 28 & 45,2 \\
\hline & Total & 43 & 100 & 62 & 100 \\
\hline
\end{tabular}

Berdasarkan tabel 1 di atas secara umum memperlihatkan bahwa dari 43 responden di rumah sakit pemerintah lebih dari setengahnya dengan kepemimpinan klinis baik yaitu sebanyak 22 responden $(51,2 \%)$. Sedangkan dari 62 responden di rumah sakit swasta lebih dari setengahnya dengan kepemimpinan klinis baik yaitu sebanyak 33 responden $(53,2 \%)$. Secara khusus, semua domain dari kepemimpinan klinis di rumah sakit pemerintah dan rumah sakit swasta antara baik dan kurang hampir sama.

\section{Analisis Bivariat}

Perbandingan kepemimpinan klinis perawat berdasarkan pendekatan clinical leadership competence framework di Rumah Sakit Pemerintah dan Rumah Sakit Swasta di Kutacane menggunakan uji beda rata-rata independen (Independent sample t-test). Secara rinci dapat dilihat pada tabel 2.
Tabel 2

Perbandingan Kepemimpinan Klinis Perawat Berdasarkan Clinical Leadership Competency Framework di Rumah Sakit Pemerintah dan Rumah Sakit Swasta di Kutacane Tahun 2019

\begin{tabular}{|c|c|c|c|c|c|}
\hline No. & Variabel & $\mathrm{n}$ & Mean & $\mathrm{t}$-test & $\begin{array}{c}\mathrm{p}- \\
\text { value }\end{array}$ \\
\hline 1. & $\begin{array}{l}\text { Kepemimpinan } \\
\text { Klinis Perawat }\end{array}$ & & & & \\
\hline & $\begin{array}{l}\text { - RS. } \\
\text { Pemerintah } \\
\text { - RS. Swasta } \\
\text { Sub Variabel }\end{array}$ & $\begin{array}{l}43 \\
62\end{array}$ & $\begin{array}{l}96,42 \\
96,40\end{array}$ & 0,867 & 0,388 \\
\hline 2. & $\begin{array}{l}\text { Kualitas Diri } \\
\text { - } \quad \text { RS. } \\
\text { Pemerintah } \\
\text { - } \quad \text { RS. Swasta }\end{array}$ & $\begin{array}{l}43 \\
62\end{array}$ & $\begin{array}{l}20,30 \\
19,05\end{array}$ & 2,677 & 0,009 \\
\hline 3. & $\begin{array}{l}\text { Kerjasama } \\
\text { - } \mathrm{RS} . \\
\text { Pemerintah } \\
\text { - } \quad \text { RS. Swasta }\end{array}$ & $\begin{array}{l}43 \\
62\end{array}$ & $\begin{array}{l}20,42 \\
20,23\end{array}$ & 0,439 & 0,661 \\
\hline 4. & $\begin{array}{l}\text { Manajemen } \\
\text { asuhan } \\
\text { keperawatan } \\
\text { - } \text { RS. } \\
\text { Pemerintah } \\
\text { - RS. Swasta }\end{array}$ & $\begin{array}{l}43 \\
62\end{array}$ & $\begin{array}{l}20,02 \\
19,06\end{array}$ & 1,189 & 0,237 \\
\hline 5. & $\begin{array}{l}\text { Pengembangan } \\
\text { layanan } \\
\text { keperawatan } \\
\text { - RS. } \\
\text { Pemerintah } \\
\text { - RS. Swasta }\end{array}$ & $\begin{array}{l}43 \\
62\end{array}$ & $\begin{array}{l}18,49 \\
18,44\end{array}$ & 0,086 & 0,932 \\
\hline 6. & $\begin{array}{l}\text { Kemampuan } \\
\text { change agent } \\
\text { - } \text { RS. } \\
\text { Pemerintah } \\
\text { - RS. Swasta }\end{array}$ & $\begin{array}{l}43 \\
62\end{array}$ & $\begin{array}{l}17,19 \\
17,63\end{array}$ & $\frac{-}{0,612}$ & 0,542 \\
\hline
\end{tabular}

Berdasarkan tabel 2 diatas memperlihatkan bahwa dari 43 perawat di rumah sakit pemerintah memiliki rata-rata kepemimpinan klinis $96,42 \%$ dan 62 perawat di rumah sakit swasta memiliki rata-rata kepemimpinan klinis sebesar $96,40 \%$. Berdasarkan nilai mean dapat disimpulkan bahwa kepemimpinan klinis perawat di rumah sakit pemerintah memiliki kesamaan 
dibandingkan dengan kepemimpinan klinis perawat di rumah sakit swasta. Adapun hasil uji statistic independent sample t-test diperoleh nilai t-test 0,867 dengan $p=0,388>(\alpha=$ 0,05) maka Ho diterima, yang berarti tidak ada perbedaan yang signifikan antara kepemimpinan klinis perawat berdasarkan CLCF di rumah sakit pemerintah dan rumah sakit swasta.

Secara khusus dari setiap domain memperlihatkan bahwa hanya domain kualitas diri perawat yang menunjukkan hasil uji statistik independent sample t-test diperoleh nlai t-test 2,677 dengan $p=0,009<(\alpha=0,05)$ maka Ho ditolak, yang berarti ada perbedaan yang signifikan antara kepemimpinan klinis berdasarkan kualitas diri perawat di rumah sakit pemerintah dan rumah sakit swasta.

\section{PEMBAHASAN}

Hasil analisis bivariat diperoleh bahwa tidak ada perbandingan yang signifikan antara kepemimpinan klinis perawat berdasarkan CLCF di rumah sakit pemerintah dan rumah sakit swasta. Kepemimpinan klinis perawat di rumah sakit pemerintah baik sebesar 51,2\% dan kepemimpinan klinis perawat di rumah sakit swasta baik sebesar 53,2\%.

Adapun secara khusus, dari lima domain kepemimpinan klinis diketahui bahwa hanya domain kualitas diri yang menunjukkan ada perbandingan yang signifikan antara kepemimpinan klinis perawat berdasarkan
CLCF domain kualitas diri di rumah sakit pemerintah dan rumah sakit swasta. Kualitas diri perawat di rumah sakit pemerintah baik sebesar $60,5 \%$ dan kualitas diri perawat di rumah sakit swasta baik sebesar 64,5\%.

Bila ditinjau dari hasil angket kualitas diri perawat di rumah sakit pemerintah mendeskripsikan seluruh perawat baik dalam menyadari nilai-nilai atau prinsip pribadi. Dengan demikian perawat memiliki kemampuan melakukan pengembangan kesadaran diri. Hal ini sesuai dengan penelitian Jack K, Smith A (2007), pengembangan kesadaran diri dapat dilakukan dengan menerima masukan dari rekan kerja sebagai pribadi perawat maupun tingkat profesional keperawatan. Sedangkan bila ditinjau dari hasil angket kualitas diri perawat di rumah sakit nurul hasanah mendeskripsikan seluruh perawat baik dalam menyadari nilainilai atau prinsip pribadi dan berani berbicara ketika ada yang bertentangan dengan etika dan nilai. Hal ini menunjukkan bahwa perawat memiliki kemampuan pengembangan kesadaran diri dan tindakan berintegritas. Menurut Butts (2007), perawat yang mempunyai integritas moral akan bertindak secara konsisten dengan nilai-nilai pribadi dan professional serta menunjukkan karakter diri seperti kejujuran, kebenaran dan keberanian.

Namun hasil angket kualitas diri perawat di rumah sakit pemerintah mendeskripsikan hampir sebagian perawat kurang dalam 
Yusnaini', Lisnawati Lubis ${ }^{2}$, Perbandingan Kepemimpinan Klinis Perawat berdasarkan Pendekatan Clinical Leadership Competency Framework di Rumah Sakit Pemerintah dengan Rumah Sakit Swasta di Kutacane Tahun 2019

merencanakan beban kerja dan berkomitmen. Kondisi ini memperlihatkan bahwa perawat kurang dalam melakukan manajemen diri. Menurut Suyanto (2009), perawat profesional harus dapat memimpin dan mengatur dirinya sediri. Hal ini disebabkan tanpa kemampuan manajemen diri yang baik maka sulit bagi perawat untuk dapat memberikan pelayanan asuhan keperawatan yang profesional kepada pasien. Longh, et all. (2015), manajemen diri mendukung perawat mengembangkan pengetahuan, kepercayaan diri dan keterampilan yang dibutuhkan untuk membuat keputusan dan tindakan yang optimal.

Adapun hasil angket kualitas diri perawat di rumah sakit Nurul Hasanah mendeskripsikan bahwa sebagian kecil perawat kurang aktif mencari kesempatan untuk belajar dan berkembang serta perawat juga kurang dalam mengaplikasikan pembelajaran. Dengan demikian perawat kurang dalam melakukan pengembangan pribadi berkelanjutan. Hasil penelitian Jaradeh dan Hamdeh (2010) di RS Amman Jordan didapatkan bahwa pengembangan profesional berkelanjutan menjadi motivator utama dalam meningkatkan kualitas asuhan keperawatan. Pengembangan profesional berkelanjutan memotivasi dalam 4 hal yaitu meningkatkan kinerja, meningkatkan kinerja, meningkatkan pengetahuan profesional, meningkatkan harga diri dan meningkatkan status profesi.
Menurut analisis peneliti bahwa kualitas perawat dalam pengembangan kesadaran diri, manajemen diri dan tindakan berintegritas sudah baik, namun perawat masih kurang dalam pengembangan pribadi berkelanjutan. Hal ini terbukti sebagian besar perawat dengan jenjang pendidikan D-III Keperawatan. Jadi perawat masih berada pada tahap awal pendidikan keperawatan yang berperan sebagai vokasional. Pengembangan pribadi berkelanjutan dapat dilakukan perawat melalui pendidikan formal dan informal (seminar, pelatihan dan branchmaking).

\section{SIMPULAN}

Hasil penelitian ini dapat disimpulkan sebagai berikut:

1. Kepemimpinan klinis perawat berdasarkan pendekatan clinical leadership competence framework di rumah sakit pemerintah mayoritas berada pada kategori baik

2. Kepemimpinan klinis perawat berdasarkan pendekatan clinical leadership competence framework di rumah sakit swasta mayoritas berada pada kategori baik

3. Tidak ada perbedaan antara kepemimpinan klinis perawat berdasarkan pendekatan clinical leadership competence framework di rumah sakit pemerintah dan rumah sakit swasta 
SARAN

Penelitian yang dilakukan ini memberikan hasil yang dapat meningkatkan kualitas pelayanan keperawatan di rumah sakit melalui kepemimpinan klinis dengan adanya dukungan pihak manajerial bagi perawat melalui pendidikan, pelatihan dan mengevaluasi efektifitas kepemimpinan klinis berdasarkan clinical leadership competence framework. Peneliti selanjutnya dapat melakukan eksperimen dengan menggunakan clinical leadership competence framework untuk meningkatkan kepemimpinan klinis perawat.

\section{DAFTAR PUSTAKA}

Jack K, Smith A. (2007). Promoting SelftAwarenee in Nurses to Improve Nursing Practice. Nursing Standard. 21: 47- 52.

Butts (2007). Ethics in Professional Nursing Practice.http://samples.jbpub.com/ 978 1449649005/22183_CH03_Pass4.pdf.

Suyanto. (2009). Mengenal Kepemimpinan dan Manajemen Keperawatan di Rumah Sakit. Yogyakarta: Mitra Cendikia Press.

Longh, A., Fagan, P.L., Fenner, J.A. dan Kidd, L. (2015). A Practical Guide to SelfManagement Support. London: The Health Foundation.

Simon. (2014). Clinical Leadership:The Role of Clinicians in eHealth Reform. Australia: White Paper

Ferguson, L., Calvert, J., Davie, M., Fallon, M. \& Fred, N. (2007). Clinical Leadership: Using Observations of Care to Fokus Risk Management and Quality Improvement Activities in the Clinical
Setting. Contemporary Nurse. Vol. 24 (2): 212-224

Ruedy, J. \& Ogilvie, R. (2004). Adverse events: past and future http://search.proquest.com/docview/20481 3600 ? accountid $=50268$

Willcocks, S. G. ( 2012). Exploring Leadership Effectiveness: Nurses as Clinical Leaders in the NHS. Leadership in Health Service;BradFord. Vol. 25 (1): 8-19.

Doherty, Jane. (2014). Improving Public Hospitals Through Effective Clinical Leadership Lesson From South Africa. http://www.municipalservicesproject.org/s ites/ municipal servicesproject.org/files/ publications/Doherty_Background_Resear ch_2014.pdf

NHS Leadership Academy. (2012). The Leadership Framework Self assessment tool. Coventry House, University of Warwick Campus, Coventry, CV4 7AL

NHS. (2011). A Framework to Develop Leadership Potential. Journal of Nursing Management, 18: 29-32.

Blaber \& Harris. (2014). Clinical Leadership for Paramedics. England: University Press

Jaradeh \& Hamdeh (2010). Nurses' Experience of Continuous Professional Development. J Med. Vol 44 (3): 313-322 